\title{
ABSTRAK \\ Sosiolek Pekerja Seks Komersial Berstatus Mahasiswa di Lingkungan Kampus dan Lingkungan Prostitusi sebagai Representasi Status Sosial
}

\author{
R. Riana, S. Setiadi, dan E. D. Pratamanti \\ Fakultas Hukum, Universitas Semarang
}

\begin{abstract}
Every social group has their own sociolect which represent their specific intention. In order to understand its intention, whether or not it can really represent a particular social class, this research therefore purposed to explain the sociolect used by college students who is practising prostitution in their site and also in their college. The descriptions and analyses intended to discover the intention of respondents' sociolect as a mean of representation of their social status. The research data are obtained from the usage of sosiolect by female college students who are practising prostitution at the prostitution sites and at their college. Data collection techniques are using observations, recordings, and interview. Data analyses utilize qualitative methods. According to data analyses, respondents has their specific, unique and particular sosiolect at their prostitution sites and at their college. It is intended to make their communication easier with another prostitutes and their customer. In addition, their particular sociolect is used to protect their privation, the prostitutes and their customer, when they are out site. They employ both verbal and nonverbal sociolects. As the conclusion, their specific and unique sociolect is indeed a way to represent their social status and have specific intention understandable from their own standpoint.
\end{abstract}

Keywords: sociolect, speech, social status

\section{PENDAHULUAN}

\section{Latar Belakang Masalah}

Tujuan berkomunikasi dengan lawan bicara adalah untuk menyampaikan pesan dan menjalin hubungan sosial. Menurut Anam (dalam Wicaksana 2011) bahwa untuk menjalin hubungan sosial dapat dilakukan dengan menggunakan strategi tertentu, baik dengan menggunakan ungkapan kesopanan, ungkapan implisit, dan basa-basi. Strategi tersebut dilakukan oleh pembicara dan lawan bicara agar proses komunikasi berjalan baik, sehingga pesan dapat dipahami tanpa merusak hubungan sosial di antara keduanya. Startegi komunikasi merupakan faktor nonlinguistik dalam proses berkomunikasi. Penggunaan bahasa yang santun, sopan, sistematis, teratur, jelas, dan lugas mencerminkan bahwa pribadi penuturnya berbudi. Sebaliknya, menggunakan bahasa yang sarkasme, menghujat, memaki, mengejek, atau melecehkan mencitrakan pribadi yang tidak berbudi.

Betitik tolakt dari fungsi bahasa sebagai alat komunikasi sosial, muncullah anggapan bahwa hubungan sosial manusia dengan sesamanya di masyarakat dipengaruhi dan memengaruhi bahasa yang digunakan. Masyarakat akan dapat menangkap garis besar sifat seseorang melalui bahasa yang digunakannya, begitu pula manusia akan memberikan tanggapan dengan sikap yang sesuai. Misalnya, manusia yang bertutur kata sopan dan baik akan diterima dengan sikap yang baik pula oleh masyarakat sekitarnya

Hal ini tentu saja berlaku dua arah. Manusia cenderung akan bersikap baik di lingkungan sosialnya agar dapat diterima baik pula. Cara penyesuaian diri ini tergambar melalui sikapnya yang dimaksudkan agar orang lain dapat melihat status sosial yang berusaha dibentuknya. Sikap sosial guna membentuk pemahaman tentang status sosial yang dibentuk seseorang salah satunya direpresentasikan melalui bahasa yang digunakan. Bahasa yang digunakan dalam kehidupan bermasyarakat dapat berupa bahasa formal maupun nonformal. Keduanya dipengaruhi oleh situasi dan kondisi yang melingkupinya, baik bahasa normal dan nonformal digunakan oleh seseorang dengan berbagai variasi. Variasi timbul karena adanya kode, lambang, ikon. Beberapa hal tersebut kemudian membentuk dialek, idiolek, dan sosiolek.

Dalam lingkungan masyarakat mana pun dapat ditemui kelompok-kelompok sosial yang terbentuk sebagai akibat adanya kesamaan prinsip, tujuan, kultur, dan kepentingan. Hal ini ditemukan pula dalam lingkungan para pekerja seks komersial (selanjutnya disebut PSK) yang bertempat di lokalisasi Sunan Kuning, Semarang. Lokalisasi yang terkenal besar dan menjadi tempat prostitusi di Kota Semarang ini memiliki wanita PSK lebih dari 300 orang. Ada 
sebagian yang menetap di lokalisasi tersebut, sedangkan sebagian besar yang lain tinggal di tempat lain. Berdasarkan data yang diperoleh dari awak pengelola lokalisasi Sunan Kuning diketahui bahwa 30\% wanita PSK berstatus sebagai mahasiswa.

Wanita PSK yang berstatus sebagai mahasiswa juga menggunakan jargon tertentu dalam perbincangan mereka di lingkungan lokalisasi. Ketika kembali ke lingkungan masyarakat luar, mereka akan menggunakan bahasa yang berbeda. Bagaimana pun wanita PSK, khususnya yang berstatus sebagai mahasiswa, juga makhluk sosial yang membutuhkan interaksi dan komunikasi dengan dunia luar. Namun, karena faktor pekerjaan, mereka merasa perlu berhati-hati dalam berbahasa.

\section{Rumusan Masalah}

Berdasarkan latar belakang tersebut rumusan masalahnya adalah sebagai berikut.

1. Bagaimanakah sosiolek yang digunakan oleh para PSK berstatus mahasiswa di lingkungan portitusi?

2. Bagaimanakah sosiolek yang digunakan oleh para PSK berstatus mahasiswa di lingkungan kampus?

3. Bagaimana dan apakah sosiolek yang digunakan bertujuan untuk merepresentasikan status sosial yang berusaha dibentuk oleh para PSK berstatus mahasiswa?

\section{Tujuan Penelitian}

berikut:

Tujuan penelitian ini adalah sebagai

1. mendeskripsikan dan menjelaskan sosiolek yang digunakan oleh para PSK berstatus mahasiswa di lingkungan prostitusi,

2. mendeskripsikan dan menjelaskan sosiolek yang digunakan oleh para PSK berstatus mahasiswa di lingkungan kampus, dan

3. mendeskripsikan dan menjelaskan sosiolek yang digunakan bertujuan untuk merepresentasikan status sosial yang berusaha dibentuk oleh para PSK berstatus mahasiswa.

\section{KAJIAN PUSTAKA}

Kajian pustaka dalam penelitian ini mencakupi hakikat bahasa, fungsi bahasa, ragam dan variasi bahasa, sosiolek, sikap berbahasa, status sosial.

\section{Hakikat Bahasa}

Bahasa pada hakikatnya adalah sesuatu yang digunakan untuk berkomunikasi dan mengirimkan pesan dari si penutur kepada lawan tuturnya. Bahasa dalam kehidupan seharihari dapat berupa bahasa verbal dan bahasa nonverbal. Bahasa verbal berupa kata-kata atau lambang bunyi yang diucapkan atau ditulis, sedangkan bahasa nonverbal adalah bahasa yang tidak berupa lambang bunyi. Bahasa nonverbal dapat digambarkan melalui gerak-gerik, mimik wajah, gestur tubuh, lirikan mata, logat atau lagu bahasa, dan lain sebagainya. Bahasa verbal dan nonverbal dapat saling melengkapi untuk menyampaikan pesan dari si penutur kepada lawan tuturnya.

\section{Fungsi Bahasa}

Bahasa mempunyai fungsi yang sangat beragam. Hal ini dikarenakan bahasa tidak bisa lepas dari masyarakat penggunanya dalam kehidupan sehari-hari di berbagai aspek. Masyarakat menggunakan bahasa untuk berbagai keperluannya serta menggambarkannya dalam sikap dan tingkah laku. Oleh karena itu, tidak dapat dipungkiri bahwa bahasa merupakan cerminan identitas suatu masyarakat, bahkan identitas masingmasing individu.

Beragam fungsi bahasa dikemukakan oleh banyak ahli. Tentu masing-masing mempunyai pengelompokkan fungsi bahasa yang berbeda-beda tergantung dari segi mana bahasa dilihat. Akan tetapi, pada dasarnya semua mengemukakan bahwa bahasa mempunyai fungsi utama sebagai alat komunikasi.

\section{Ragam dan Variasi Bahasa}

Kemampuan berkomunikasi setiap orang bervariasi. Variasi atau ragam berbahasa ini dipengaruhi oleh penguasaan bahasa ibu, atau bahasa yang lain yang diperoleh dalam pendidikan atau dalam pergaulannya dengan penutur bahasa di luar lingkungannya. Menurut Halliday (dalam Chaer dan Agustina 1995:45) bahwa kemampuan komunikatif adalah kemampuan bertutur atau kemampuan menggunakan bahasa sesuai dengan fungsi dan situasi serta norma-norma penggunaan bahasa dengan konteks situasi dan sosialnya. Pengguna bahasa dapat dikatakan mempunyai kemampuan komunikatif apabila bisa membedakan kalimat yang gramatikal dengan yang tidak gramatikal, bisa memilih bentuk-bentuk bahasa yang sesuai dengan situasinya, mampu memilih ungkapan 
sesuai dengan tingkah laku dan situasinya. Selain itu, juga bisa menginterpretasikan makna referensial, bisa menafsirkan makna kontekstual dan makna situasional.

\section{Sikap Berbahasa}

Bahasa yang notabene adalah alat komunikasi sosial mempunyai peranan yang vital dalam lingkungan sosial masyarakat. Dalam lingkungan sosial ini, seseorang akan menggunakan bahasa dengan dipengaruhi oleh beberapa hal. Beberapa hal tersebut, antara lain faktor kultur, kepentingan, status sosial, tanggapan masyarakat, dan tingkat pendidikan. Maka tak salah jika dikatakan bahwa bahasa adalah cerminan pribadi seseorang (Masnur 2009:12).

\section{Status Sosial}

Sitorus (2000) mendefenisikan status sosial bahwa hal tersebut merupakan kedudukan seseorang di masyarakat, di mana didasarkan pada pembedaan masyarakat ke dalam kelas-kelas secara vertikal, yang di wujudkan dengan adanya tingkatan masyarakat dari yang tinggi ke yang lebih rendah dengan mengacu pada pengelompokkan menurut kekayaan Kelas sosial biasa digunakan hanya untuk lapisan berdasarkan unsur ekonomis.

\section{METODE PENELITIAN}

Metode penelitian ini mencakupi jenis penelitian, wujud data dan sumber data, metode pengumpulan data, metode analisis data, dan pemaparan hasil penelitian.

\section{Jenis Penelitian}

Penelitian ini merupakan penelitian studi kasus, yaitu penelitian yang mengamati dan mempelajari bahasa sosiolek yang digunakan oleh wanita para pekerja seks komersial berstatus mahasiswa di lingkungan prostitusi dan lingkungan kampus. Dalam penelitian ini juga diamati apakah bahasa yang digunakan dapat merepresentasikan status sosial wanita para PSK berstatus mahasiswa.

Penelitian ini menggunakan metode pendekatan kualitatif. Pendekatan ini digunakan karena data yang dikumpulkan berupa tuturan wanita para PSK berstatus mahasiswa. Penelitian kualitatif ini bersifat deskriptif dengan memaparkan bahasa sosiolek yang digunakan oleh wanita para PKS berstatus mahasiswa di lingkungan prostitusi dan lingkungan kampus.
Akan dideskripsikan pula, apakah bahasa yang digunakan dapat merepresentasikan status sosial wanita para PSK berstatus mahasiswa di lingkungan sosialnya.

\section{Wujud Data dan Sumber Data}

Wujud penelitian ini adalah pemakaian sosiolek yang digunakan oleh wanita para PSK berstatus mahasiswa di lingkungan kampus dan lingkungan prostitusi. Sosiolek tersebut kemudian digunakan untuk menganalisis perbedaan bahasa yang digunakan ketika mereka berada di lingkungan kampus dan ketika mereka berada di lingkungan portitusi. Melalui analisis ini, diketahui bahwa apakah sosiolek yang mereka gunakan merepresentasikan status sosial di kehidupan bermasyarakat atau tidak. Sementara itu, sumber data penelitian ini adalah sosiolek yang digunakan oleh wanita para PSK berstatus mahasiswa di lingkungan sosialnya.

\section{Metode Pengumpulan Data}

Di dalam pengumpulan data digunakan metode observasi, teknik rekam, wawancara. Observasi (simak) dan teknik rekam dilakukan terhadap tuturan wanita para PSK berstatus mahasiswa di lingkungan prostitusi Sunan Kuning, Semarang. Pengumpulan dengan teknik observasi dilakukan dengan pengamatan dan pencatatan secara sistematik terhadap gejala yang tampak pada objek penelitian. Peneliti menggunakan pengamatan dan pencatatan yang dilakukan terhadap objek di tempat kejadian atau berlangsungnya peristiwa, sehingga observer berada bersama objek yang diteliti. Kegiatan ini disebut observasi langsung (Rachman 1993:71).

Jumlah PSK yang tergabung di lokalisasi Sunan Kuning, Semarang, yaitu 457 orang. Dari total PSK tersebut, 136 di antaranya adalah PSK berstatus mahasiswa. Subjek penelitian diambil $20 \%$ dari jumlah total PSK berstatus mahasiswa, yaitu 27 orang. Observasi dan wawancara dilakukan terhadap 27 subjek. Hasil observasi dan wawancara kemudian dicatat untuk dianalisis.

Setelah melakukan observasi terhadap objek yang diteliti, peneliti melakukan proses perekaman interaksi atau tuturan wanita para PSK berstatus mahasiswa di lingkungan prostitusi Sunan Kuning, Semarang. Alat perekam untuk memperoleh data menggunakan tape recorder dan handphone.

Sementara itu, wawancara dilakukan pula terhadap wanita para PSK berstatus 
mahasiswa di lingkungan prostitusi Sunan Kuning, Semarang, beberapa awak lingkungan prostitusi, dan konsumen prostitusi. Wawancara ini dilakukan terhadap 20\% dari jumlah wanita PSK, yaitu 27 orang. Selain itu, dilakukan pula wawancara terhadap 2 orang awak lingkungan prostitusi, dan 5 konsumen prostitusi yang terlibat. Jawaban responden tercantum dalam kuisioner. Data tersebut selanjutnya ditabulasi.

\section{Metode Analisis Data}

Dalam penelitian ini dilakukan analisis kualitatif terhadap tuturan wanita PSK, awak lingkungan prostitusi, dan konsumen prostitusi. Tuturan yang dianalisis mencakupi berbagai variasi bahasa berupa ikon, simbol, lambang, kode, sandi, dan dialek yang membentuk sosiolek yang digunakan di lingkungan prostitusi dan lingkungan kampus. Selain tuturan, analisis juga dilakukan terhadap hasil wawancara dan observasi.

\section{Pemaparan Hasil Penelitian}

Pemaparan hasil penelitian ini menggunakan metode penyajian informal karena bentuk paparannya berupa kata-kata biasa. Hal ini sesuai dengan pendapat Sudaryanto (2003:145) bahwa metode penyajian informal adalah perumusan dengan kata-kata biasa walaupun dengan terminologi yang teknis sifatnya. Dengan demikian, pemaparan hasil penelitian ini disajikan dengan deskripsi verbal dengan kata-kata tanpa lambang.

\section{HASIL DAN PEMBAHASAN}

Penelitian tentang sosiolek PSK berstatus mahasiswa di lingkungan kampus dan lingkungan prostitusi sebagai representasi status sosial sudah dilakukan dalam kurun waktu kurang lebih tiga bulan. Penelitian ini diawali dengan survei prapenelitian pada bulan Januari 2016 sebanyak dua kali kunjungan.

Pada penelitian bulan Agustus 2017, diperoleh data bahwa ada lebih dari 450 PSK yang tinggal di Sunan Kuning. Selain itu, masih ada sekitar 200 PSK Sunan Kuning yang tinggal di luar lokalisasi. Dari total PSK yang ada, 30\%-nya berstatus mahasiswa. Para PSK berstatus mahasiswa ini berkuliah di berbagai perguruan tinggi di Kota Semarang. Ada pula yang mengambil studi di beberapa kampus kecil di Kendal, Kudus, dan Jepara.

Tim peneliti mengambil subjek penelitian $20 \%$ dari total PSK berstatus mahasiswa, yaitu sebanyak 27 orang. Melalui observasi dan wawancara terhadap 27 orang tersebut, diperoleh data yang kemudian dianalisis untuk menjawab rumusan masalah yang ada. Di antara 27 subjek tersebut, ada 7 subjek yang memberikan data lengkap. Hal ini dipengaruhi pula oleh pertimbangan bahwa tujuh orang tersebut adalah PSK berstatus mahasiswa yang benar-benar aktif berkuliah dan memunyai prestasi yang baik di kampusnya. Selain itu, diambil pula subjek yang berkuliah di Kota Semarang dengan pertimbangan bahwa kampus di Kota Semarang memiliki ragam bahasa sosial yang beranekaragam dan membuka banyak kesempatan untuk pergaulan yang luas.

\section{Deskripsi dan Analisis Sosiolek PSK Berstatus Mahasiswa di Lingkungan Prostitusi}

Wanita PSK berstatus sebagai mahasiswa juga menggunakan jargon tertentu dalam perbincangan mereka di lingkungan lokalisasi. Ketika kembali ke lingkungan masyarakat luar, mereka akan menggunakan bahasa yang berbeda. Bagaimana pun wanita PSK, khususnya yang berstatus sebagai mahasiswa, juga makhluk sosial yang membutuhkan interaksi dan komunikasi dengan dunia luar. Terlebih karena status mereka sebagai mahasiswa. Namun, karena faktor pekerjaan, mereka merasa perlu berhati-hati dalam berbahasa. Hal ini disampaikan oleh TR, salah seorang PSK berstatus mahasiswa di perguruan tinggi di kota Semarang pada data 8 .

TR adalah mahasiswa di salah satu perguruan tinggi di Kota Semarang. Tinggal di Kendal. TR adalah PSK yang jarang melayani konsumen lepas karena dia punya simpanan yang terikat dengan perjanjian tertentu antara dua belah pihak. Menurut penuturannya, TR mendapat banyak materi dari simpanannya, antara lain berupa rumah dan mobil serta jatah bulanan. TR berkuliah di kampus yang sama dengan DL. Jika bertemu di kampus, mereka seringkali berbincang dengan tuturan yang tidak diketahui artinya oleh masyarakat luas.

Meskipun TR berbincang dengan rekan sesama PSK, jika berinteraksi di lingkungan luar prostitusi, mereka menggunakan tuturan yang tidak diketahui artinya oleh masyarakat luas. Hal ini disampaikan pula oleh PSK berinisial NT dalam data 7.

NT adalah mahasiswa di salah satu perguruan tinggi swasta di kota Kudus. Tinggal di Kota Semarang. NT mengatakan bahwa 
ketika tawar-menawar dengan konsumen di luar lingkungan prostitusi, mereka menggunakan bahasa yang sedapat mungkin tidak bisa dipahami oleh masyarakat luar. Hal ini dimaksudkan untuk menjaga privasi kedua belah pihak. Di tempat umum mereka cenderung menggunakan kalimat yang singkat.

Berdasarkan data yang diperoleh, berikut diuraikan sosiolek yang digunakan oleh PSK berstatus mahasiswa di lingkungan prostitusi. Sosiolek yang digunakan berupa bahasa verbal dan bahasa nonverbal. Bahasa verbal adalah bahasa yang diungkapkan dengan kata-kata atau lambang bunyi. Bahasa nonverbal adalah bahasa yang diungkapkan tidak dengan kata-kata atau lambang bunyi melainkan dengan mimik wajah, sikap tubuh, gerak mata, cara berpakaian dan penggunaan perhiasan, dll.

\section{Sosiolek Verbal PSK Berstatus Mahasiswa di Lingkungan Prostitusi}

\section{Sosiolek Verbal Sesama PSK Berstatus Mahasiswa di Lingkungan Prostitusi}

Sesama PSK seringkali menggunakan sosiolek ketika berbicara dengan maksud agar tidak keseluruhan topik obrolan mereka dipahami oleh pelanggan atau masyarakat luar. Hal ini dilakukan karena mereka beranggapan tetap memunyai privasi yang tidak boleh diketahui oleh masyarakat lain. Selain itu, menurut penuturan salah satu PSK berstatus mahasiswa berinisial MG, mereka menggunakan sosiolek yang sudah menjadi istilah khas sejak dulu.

MG mengungkapkan pula bahwa PSK berstatus mahasiswa juga memunyai komunitas khusus di dalam lingkungan prostitusi. Komunitas ini keseluruhannya beranggotakan PSK yang masih berstatus sebagai mahasiswa dari berbagai kampus. Hal ini terlihat pada data 3 sebagai berikut:

Dalam beberapa kali perjumpaan dengan peneliti, MG terbiasa menggunakan baju kasual tertutup hingga ke batas leher dan berlengan panjang. Hal ini diakui MG sebagai kebiasaannya di kampus. Selain itu, MG selalu memakai kalung dengan liontin burung dara yang menjadi simbol komunitasnya. Komunitas yang diikuti MG adalah komunitas khusus PSK berstatus mahasiswa dengan anggota dari berbagai kampus di Semarang dan sekitarnya. Mereka memunyai bahasa dan ciri khas antaranggota komunitas.

Selain MG, LD juga bergabung dengan komunitas PSK berstatus mahasiswa yang berbeda dengan komunitas yang diikuti oleh MG. Hal ini tampak pada data 3 sebagai berikut:

LD merupakan PSK yang berkuliah di salah satu PTS di Semarang. Tinggal di Semarang. LD bercerita bahwa ia tergabung dalam komunitas PSK berstatus mahasiswa di Semarang. Komunitas ini beranggotakan lebih dari 10 orang dengan berbagai asal perguruan tinggi tempat kuliah para PSK. Biasanya mereka berkomunikasi melalui ponsel dan sesekali bertemu di rumah makan atau caffé.

Para PSK berstatus mahasiswa tentu juga menuturkan sosiolek yang ada di lingkungan prostitusi sama seperti PSK yang lain. Mereka menggunakan istilah-istilah tertentu sebagai analogi untuk mengungkapkan berbagai hal yang berhubungan dengan pekerjaan dan mitra kerja mereka.

TR merupakan mahasiswa di salah satu perguruan tinggi di Kota Semarang, tinggal di Kendal. TR merupakan PK yang jarang melayani konsumen lepas karena dia punya simpanan yang terikat dengan perjanjian tertentu antara dua belah pihak. Menurut penuturannya, TR mendapat banyak materi dari simpanannya, antara lain berupa rumah dan mobil serta jatah bulanan. TR berkuliah di kampus yang sama dengan DL. Jika bertemu di kampus, mereka seringkali berbincang dengan tuturan yang tak diketahui artinya oleh masyarakat luas.

TR, DL, dan beberapa teman lain sesama PSK seringkali mengibaratkan keadaan finansial para pelanggannya dengan merek kosmetik. Hal ini dimaksudkan agar orangorang di sekitar mereka menangkap maksud lain dari pembicaraan mereka. Merek kosmetik yang dimaksud antara lain Revlon, Wardah, Viva, Marina, dan Ponds.

Ketika berbincang tentang pelanggan, mereka seringkali menyebut pelanggan dengan menganalogikannya dengan merek make-up seperti Marina, Revlon, Viva, Wardah, dan Ponds. Mereka menganalogikan kemampuan finansial si pelanggan yang memengaruhi upah mereka. Pelanggan yang hanya mampu memberi upah minim mereka sebut Viva, seperti make-up merek Viva yang tergolong murah di pasaran, sedangkan pelanggan yang mampu membayar tinggi mereka sebut dengan Revlon.

Selain menganalogikan dengan merek make-up, para PSK juga menyebut pakaian atau cara berpakaian para pelanggan. Hal ini tampak pada tuturan yang dicontohkan oleh PSK berinisial MG sebagaimana data berikut. 
a. Si Keki penginnya maen sama kamu. Jare rong jam.(Si Keki inginnya main dengan kamu. Katanya dua jam).

b. Lha kae hem kotak wingi kae wes rampungan durung? Bathi piro? Opo mung nge-room?

(Lha itu Si Hem Kotak itu sudah selesai belum? Untung berapa? Apa cuma ngeroom?)

Si Keki maksudnya adalah pelanggan yang berbaju seragam keki atau baju dinas yang biasa dipakai oleh pegawai, sedangkan Si Hem Kotak adalah pelanggan berbaju hem kotak-kotak.

Para PSK juga menggunakan istilahistilah yang digunakan untuk menyebut hal-hal yang menjurus pada aktivitas seksual yang biasa mereka lakukan dengan para pelanggan. Hal ini terlihat pada tuturan dalam data 10 sebagai berikut.

SC mengatakan bahwa mereka seringkali melemparkan candaan atau gurauan dengan teman sesama PSK, baik di lingkungan prostitusi maupun di lingkungan luar. Candaan yang diucapkan seringkali bernada seksual dan cabul.

Berbagai tuturan yang sering diucapkan, antara lain:

"Cie... dapat sosis sapi."

"Alah sosis sapi mayonnaise-e sitik."

"Diublek sek to ben akeh."

\section{Percakapan melibatkan NT dan VK. \\ $N T$ : Wes rampungan? \\ $V K:$ Wes. \\ $N T$ : Langganan po tuku tok? \\ $V K$ : Nyicip tok.}

Percakapan tersebut menjurus pada aktivitas seksual yang baru saja dilakukan oleh si $\mathrm{B}$ dengan pelanggannya. Si A menyebut alat kelamin pelanggan B dengan istilah sosis. B menanggapinya dengan mengatakan bahwa mayonnaise yang diibaratkan sebagai sperma yang dikeluarkan hanya sedikit. B meledek A dengan menyuruhnya mengaduk hal yang dibicakan agar "mayonnaise" yang dikeluarkan kental.

Di percakapan kedua, NT menanyakan apakah VK sudah selesai melayani pelanggan atau belum. Di lingkungan prostitusi, mereka mengatakan bahwa pelanggan yang hanya datang sekali dua kali hanya mencicipi atau sekadar "tuku". Sementara itu, yang rutin datang berkunjung disebut "langganan".

Selain obrolan serius, para PSK seringkali saling melemparkan perkataan dengan maksud gurauan. Gurauan yang mereka lontarkan dapat bermuatan porno yang menjurus pada aktivitas seks maupun tidak. Hal ini terlihat pada tuturan dalam data berikut.

\section{NT : Nge-room tok tapi dibayar? \\ LD : Yo karo ngamar. \\ NT: Nggak apa lah. \\ LD : Ngganteng. Tajir. \\ NT : Enak to. Ajak jalan juga. Sisan. \\ LD : Iya. Seminggu pake. Itungan belakangan. \\ $N T$ : Lumayan. Kalo dah nyicip juga minta lagi rupo-rupo ngono kuwi.}

Percakapan kedua melibatkan dua PSK berinisial NT dan LD yang berbincang serius. Melalui perbincangan mereka dapat dilihat adanya sosiolek ngamar, nge-room, pake, dan nyicip. Istilah-istilah ini mereka gunakan secara turun-temurun baik ketika berbincang dengan sesama PSK, awak prostitusi, maupun pelanggan. Pelanggan yang datang pun rata-rata sudah memahami istilah-istilah tersebut karena seringkali diucapkan oleh para PSK yang melayani mereka.

\section{Sosiolek Verbal PSK Berstatus Mahasiswa dengan Pelanggan di Lingkungan Prostitusi}

PSK dan pelanggan kadang sering pula berbincang tentang hal lain di luar konteks hubungan mereka. Tidak jarang pelanggan menanyakan profesi dan status PSK di luar profesinya. Dalam perbincangan tersebut, PSK dan pelanggan sering tidak mengutarakan topik pembicaraan mereka secara terang-terangan, tetapi dengan analogi tertentu. Mereka menggunakan kata nyambi atau jualan untuk menyebut profesi sebagai PSK. Penggunakan kata mitra atau klien untuk menyebut pelanggan, maen yang berarti kencan, dan warung yang berarti lokalisasi.

DL adalah mahasiswa di salah satu perguruan tinggi di Kota Semarang. DL menjalani profesinya lebih dari empat tahun terakhir. DL jarang melayani konsumen lepas karena memunyai simpanan yang menjadi pelanggan tetap. DL mendapat jatah bulanan dari pelanggan tetapnya lengkap dengan bonus rumah, mobil dan apartemen. Karena sudah memunyai hubunga erat dengan simpanannya selayaknya suami istri, DL tidak banyak menggunakan tuturan bernada sensual atau tersirat ketika berada di lingkungan luar. 
Di kampus, DL selalu menggunakan jilbab dengan gaya berpakaian yang elegan. DL adalah tipe mahasiswa yang menutup diri dari lingkungaan sosial dan membatasi pergaulan dengan teman kampus. Dia hanya ke kampus jika ada jadwal kuliah. Di desa asalnya, DL dikenal sebagai pegawai bank yang sukses dengan gaji besar, sehingga dapat membeli rumah, mobil, melanjutkan kuliah, dan membiayai keluarganya.

Agak berbeda dengan yang telah dituturkan di atas, DL yang memunyai pelanggan sebagai simpanan dan menjalin hubungan erat seperti selayaknya sepasang suami istri merasa lebih bebas berbincang dengan pelanggannya dan tidak menggunakan sosiolek yang berlebih karena pelanggannya sudah mengetahui semua seluk belum dan profesi DL. Meskipun demikian, mereka tetap berhati-hati dalam berbincang ketika berada di lingkungan luar.

\section{Sosiolek Verbal PSK Berstatus Mahasiswa di Lingkungan Prostitusi}

Para PSK berstatus mahasiswa yang ada di Sunan Kuning memunyai komunitas kecil yang keseluruhan anggotanya berstatus mahasiswa. Para PSK yang tergabung dalam komunitas ini harus berhati-hati dengan para pelanggannya karena akan memengaruhi status dan pandangan masyarakat yang mengetahui privasinya. Hal ini tentu akan berpengaruh pada lingkungan belajarnya. Mereka memunyai bahasa nonverbal yang disepakati bersama.

Dalam beberapa kali perjumpaan dengan peneliti, MG terbiasa menggunakan baju kasual tertutup hingga ke batas leher dan berlengan panjang. Hal ini diakui MG sebagai kebiasaannya di kampus. Selain itu, MG selalu memakai kalung dengan liontin burung dara yang menjadi simbol komunitasnya. Komunitas yang diikuti MG adalah komunitas khusus PSK berstatus mahasiswa dengan anggota dari berbagai kampus di Semarang dan sekitarnya. Mereka memunyai bahasa dan ciri khas antaranggotanya.

Dituturkan oleh LD bahwa ada pula PSK yang berpakaian dengan ciri khas yang ditentukan oleh komunitas yang diikutinya. Komunitas yang diikuti LD melarang anggotanya menggunakan perhiasan berwarna gold. Menurut LD, hal ini dimaksudkan sebagai ciri khas komunitas mereka. Selain itu, mereka sering menggunakan rok di bawah lutut berwarna biru muda jika ke kampus. Namun, cara berpakaian tersebut tidak selamanya digunakan oleh PSK anggota komunitas karena tidak bersifat wajib.
Menurut penuturan VK, SC, dan LD para PSK berstatus mahasiswa rata-rata mematok "nilai jual" yang tinggi kepada para pelanggannya. Hal ini mereka gunakan sebagai alat pertahanan diri yang secara tidak langsung dapat membentengi mereka dari hal yang tidak diinginkan. Selain itu, cara berpakaian mereka agak berbeda dengan PSK yang lain. Cara berpakaian dan ber-make-up para PSK berstatus mahasiswa sering disesuaikan dengan situasi dan kondisi kampus. Hal ini dimaksudkan agar status sosial mereka tidak terlihat mencolok di antara mahasiswa yang lain.

Di kampus, DL selalu menggunakan jilbab dengan gaya berpakaian yang elegan. DL merupakan tipe mahasiswa yang menutup diri dari lingkungaan sosial dan membatasi pergaulan dengan teman kampus dan ke kampus jika ada jadwal kuliah. Di desa asalnya, DL dikenal sebagai pegawai bank yang sukses dengan gaji besar sehingga dapat membeli rumah, mobil, melanjutkan kuliah, dan membiayai keluarganya.

DL memunyai gaya berpakaian yang elegan dan menggunakan jilbab karena di kampus ia dikenal sebagai mahasiswa karyawan yang sukses sebagai pegawai bank dengan gai besar. DL tidak segan menggunakan baju branded karena di kampusnya rata-rata mahasiswa memunyai selera fashion yang tinggi dan berasal dari golongan menengah ke atas. Dengan demikian, penampilan DL tidak terlihat mencolok dibandingkan dengan mahasiswa lain. Selain itu, melalui gaya berpakaiannya, DL mampu merepresentasikan status sosialnya yang dikenal sebagai pegawai bergaji besar.

Selain cara berpakaian, ada pula beberapa bahasa nonverbal yang digunakan para PSK berstatus mahasiswa di lingkungan prostitusi. Bahasa nonverbal tersebut, antara lain adalah cara memandang calon pelanggan, cara menyentuh pelanggan, cara duduk, dan cara berjalan.

\section{Deskripsi dan Analisis Sosiolek Pekerja Seks Komersial Berstatus Mahasiswa di Lingkungan Kampus}

\section{Sosiolek Verbal PSK Berstatus Mahasiswa di Lingkungan Kampus}

DL yang berstatus sebagai mahasiswa di salah satu universitas swasta di Kota Semarang s satu kampus dengan VK. Karena berkuliah di fakultas yang sama, mereka sering bertemu dan berbincang bersama. Ketika berbincang, mereka 
menggunakan banyak istilah yang mereka gunakan sebagai analogi untuk menyamarkan maksud pembicaran mereka yang sebenarnya. Hal ini terlihat pada perbincangan DL dan VK sebagai berikut.

VK : Bisnis ama si Bos masih jalan nggak?

DL : yang di bosku itu? Ya masih lah.

VK: Udah nabung jangan-jangan.

DL : Enggak. Cuma nanam saham aja. Deposit sih enggak.

VK : Makan terus ya kalau sama dia.

DL : Ya iyalah. Nggak makan ya ogah.

$V K$ : Kenyang donk.

DL : Banget. Sampe mules.

$V K$ : Eh iya, gendongannya gimana?

DL:Aman.

DL juga menuturkan bahwa sering dia dan rekannya menggunakan istilah bisnis untuk menyamarkan maksud dengan harapan pendengar mereka mengira bahwa tema perbincangan mereka seputar pekerjaan atau bisnis.

Berikut adalah narasi percakapan antara NT dan SC di kampus yang diketahui melalui rekaman dan pengamatan peneliti.

$N T$ : Mau maen ke mana habis ini?

$S C$ : Nggak ke mana-mana. Lagi capek. Udah lembur kemarin sih.

$N T$ : Sahamnya gedhe dong kalau lembur.

$S C$ : Kalau nggak gedhe nggak aku ambil. Nanggung ama yang nanam saham kecil-kecilan. Dapet capek doang.

$N T$ : Lah ada yang tetap apa kontrak semua?

$S C$ : Kontrak semua. Ben ora tanggungan. Yang penting standar terpenuhi.

NT : Enak tetap lho. Bisa dapet bonus rumah.

SC : Lha bedakmu masih pakai yang dulu po?

NT : Masih. Tetap dong.

$S C:$ Lancar?

$N T$ : lancar. Sahamnya nambah terus ki.

$S C$ : Untung trus.

NT : Iyo. Meh tutup buku juga iki. Itungitungan.

NT dan SC membicarakan pelanggan masing-masing. SC memunyai pelanggan yang menjadi simpanan yang diungkapkan dengan kata tetap, sedangkan NT hanya memiliki pelanggan lepas yang diungkapkan dengan kata kontra. Istilah maen berarti melayani pelanggan, saham berarti hubungan atau upah, bedak berarti pelanggan dengan tingkat finansial tertentu, dan tutup buku berarti pembayaran upah.

\section{Sosiolek Nonverbal PSK Berstatus Mahasiswa di Lingkungan Kampus}

DL mengatakan bahwa ketika di kampus ia sebisa mungkin membatasi pergaulannya dengan teman-teman kampus dan hanya berhubungan dengan teman-teman kelas jika ada kepentingan kuliah. Selain itu, DL selalu menggunakan pakaian tertutup, sopan, dan rapi sehingga terkesan elegan. Tatanan riasan dan make-up yang digunakan juga tidak mencolok namun menimbulkan kesan mewah. DL berusaha menyesuaikan cara berpakaiannya dengan teman-teman di kampusnya yang tergolong fashionable. Senada dengan DL, VK juga mempunyai kebiasaan yang sama.

Di kampus DL selalu menggunakan jilbab dengan gaya berpakaian yang elegan. DL adalah tipe mahasiswa yang menutup diri dari lingkungaan sosial dan membatasi pergaulan dengan teman kampus. DL hanya ke kampus jika ada jadwal kuliah.

Di desa asalnya, DL dikenal sebagai pegawai bank yang sukses dengan gaji besar sehingga dapat membeli rumah, mobil, melanjutkan kuliah, dan membiayai keluarganya.

MG dengan mayoritas teman-teman kampus yang sudah mengetahui profesinya cenderung lebih bebas bersikap. MG sama sekali tidak menutup hubungan sosialnya. MG justru menganggap bahwa sikap terbukanya yang ramah mampu mengimbangi asumsi negatif teman-temannya. Namun, meskipun teman-temannya telah mengetahui profesinya, MG tetap menjaga cara berpakaiannya di kampus. Ia selalu menggunakan baju kasual layaknya mahasiswa pada umumnya. Yang tidak pernah ketinggalan dipakai adalah kalung dengan liontin burung dara berwarna putih yang menjadi simbol komunitasnya. Hal ini diketahui dalam data 1 sebagai berikut.

Di kampus MG dikenal sebagai mahasiswa aktif yang rajin, pandai, dan supel. Prestasinya cukup memuaskan dan memunyai hubungan dekat dan akrab dengan temantemannya. Banyak teman yang mengetahui profesi MG sebagai PSK, namun MG tetap diterima baik oleh teman-temannya. 


\section{Sosiolek sebagai Representasi Status Sosial Pekerja Seks Komersial Berstatus Mahasiswa}

Sikap bahasa verbal tersebut dapat dilihat melalui percakapan antarsesama PSK berstatus mahasiswa, antara PSK berstatus mahasiswa dengan pelanggan, antara PSK berstatus mahasiswa dengan teman kampus, serta antara PSK berstatus mahasiswa dengan tim peneliti.

DL tergolong sebagai mahasiswa yang memunyai prestasi bagus di kampusnya dengan IPK yang tinggi. Menurut penuturan beberapa teman kampusnya, DL selalu mampu memeroleh nilai tinggi. Namun, DL memunyai hubungan sosial yang buruk. Teman-teman DL mengetahui DL sebagai karyawan bank yang sukses dan memiliki beberapa bisnis. Oleh karena itu, tidak heran jika DL mampu membeli rumah dan pergi ke kampus menggunakan mobil. Kemampuan finansialnya terlihat pula dari cara berpakaian dan barang-barang yang dimilikinya. Hubungan sosial DL yang buruk terlihat dari nyaris tidak ada teman kampus yang dekat dengannya. DL hanya pergi ke kampus kalau ada jadwal kuliah dan segera pergi karena kesibukannya. DL juga cenderung pendiam dan hanya menyapa teman seperlunya. Dia hanya berhubungan dengan temannya jika ada kepentingan yang menyangkut kuliahnya.

Sosiolek nonverbal yang ditunjukkan DL merupakan representasi status sosial yang berusaha dibentuknya di lingkungan masyarakat luas agar masyarakat di sekitarnya mampu memahami seperti apa status sosialnya. Ia berusaha membentuk pribadi yang tidak mudah didekati oleh orang-orang di sekitar karena ingin menyembunyikan profesinya.

Berbeda dengan DL, MG bersikap terbuka dan ramah pada teman-temannya dengan maksud agar teman-teman dan masyarakat di sekitarnya dapat menerimanya sebagai pribadi yang tidak berbeda dengan yang lain. Hal ini dilakukan MG karena pada kenyataannya profesi MG telah diketahui oleh orang-orang di sekitarnya. Dengan menjadi pribadi yang ramah dan terbuka, teman-teman MG tidak akan mengindari dan memermasalahkan profesinya.

Hal tersebut tampak dalam data 1 dan data 2 yng menyatakan keberterimaan temanteman kampus MG terhadap profesi MG serta sikap MG di kampus. Di kampus MG dikenal sebagai mahasiswa aktif yang rajin, pandai, dan supel. Prestasinya cukup memuaskan dan memunyai hubungan dekat dan akrab dengan teman-temannya. Banyak teman yang mengetahui profesi MG sebagai PKS, namun MG tetap diterima baik oleh teman-temannya.
Melalui observasi dan wawancara di kampus MG, ditemukan beberapa tuturan yang digunakan oleh MG dan teman-temannya di lingkungan kampus terkait dengan profesinya sebagai PKS.

Penggambaran status sosial terlihat pula pada sosiolek nonverbal dari segi berpakaian objek. Di lingkungan prostitusi, PSK berstatus mahasiswa berusaha berpenampilan menarik, elegan, dan sensual dengan make-up dan baju yang mahal, bagus, dan berkualitas karena ingin mematok "nilai jual" yang tinggi. Berbeda ketika mereka berada di lingkungan kampus. DL berpenampilan menarik, elegan, dan sopan untuk memerlihatkan bahwa dirinya adalah karyawan yang sukses dan memunyai kemampuan finansial tinggi. Berbeda dengan LD dan TR yang mencoba berpakaian sederhana dan jauh dari kemewahan untuk menyesuaikan status sosial dengan lingkungan sosial mereka di kampus. Cara objek dalam berbicara, memandang, dan memerlakukan teman di lingkungan prostitusi dan di lingkungan kampus pun berbeda. Hal ini dikarenakan sikap sosial yang mereka bentuk guna menunjukkan status sosial memunyai maksud yang berbeda pula.

\section{SIMPULAN DAN SARAN}

\section{Simpulan}

Para PSK berstatus mahasiswa menggunakan sosiolek yang khas di lingkungan prostutusi untuk memermudah komunikasi dengan sesama PSK dan pelanggan. Selain itu, sosiolek digunakan pula untuk melindungi privasi PSK dan pelanggan terlebih ketika mereka berada di lingkungan luar prostitusi. Sosiolek yang mereka gunakan terdiri atas sosiolek verbal dan sosiolek nonverbal.

Melalui berbagai data dan hasil analisis dapat disimpulkan bahwa sosiolek yang digunakan oleh para PKS berstatus mahasiswa mampu merepresentasikan status sosial yang dibentuknya. Sosiolek yang diungkapkan mengandung maksud tertentu yang berusaha disampaikan agar dipahami oleh lingkungan sosial mereka.

\section{Saran}

Berdasarkan temuan hasil penelitian atas sosiolek PKS berstatus mahasiswa di lingkungan kampus dan lingkungan prostitusi sebagai representasi sikap sosial bahwa pemahaman akan penggunaan bahasa oleh si penutur bahasa adalah representasi status sosial 
dan kepribadian penuturnya. Memahami kepribadian seseorang dapat melalui bahasa yang berusaha diungkapkan oleh penutur tersebut. Begitu pula dengan bahasa khas yang dimiliki oleh kelompok sosial tertentu yang digunakan oleh masing-masing penuturnya. Penutur bahasa dari kelompok sosial tertentu yang memiliki sosiolek khas dapat dipahami sebagai representasi status sosial para anggota kelompok sosial yang terkait.

Dengan demikian, peneliti memberi saran bahwa memelajari bahasa adalah hal yang penting. Selain sebagai alat komunikasi dan ekspresi diri, bahasa dapat digunakan sebagai alat untuk memahami kepribadian dan status sosial seseorang.

\section{DAFTAR PUSTAKA}

Chaer, Abdul. 2003. Linguistik Umum. Jakarta: Rineka Cipta.

Chaer, Abdul dan Leonie Agustina. 1995. Sosiolinguistik Suatu Pengantar. Rineka Cipta: Jakarta.

Keraf, Gorys. 2004. Komposisi. Flores: Nusa Indah.
Muslich, Masnur. 2009. Sebuah Kajian Sosiolinguistik. Jakarta: Bumi Aksara.

Rachman, Maulana. 1993. Metode Penelitian Kualitatif. Yogyakarta: Liberty.

Rakhmat, Jalaludin. 1994. Retorika Modern Pendekatan Praktis. Bandung: PT Remaja Rosdakarya.

Rustono. 1999. Pragmatik. Yogyakarta: Duta Wacana University Press.

Shadily, Riney. 1984. Sosial dan Status Sosial Ekonomi. Jakarta: Gramedia Pustaka Utama.

Sitorus, Ratmo. 2000. Sosial Kemasyaraka-tan. Jakarta: Bumi Aksara.

Sudaryanto. 2003. Metode dan Aneka Analisis Bahasa: Pengantar Penelitian Wacana Kebudayaan Secara Linguistis. Yogyakarta: Duta Wacana University Press.

Suhandang, Kustadi. 2004. Public Relations Perusahaan: Kajian Program Implementasi. Bandung: Yayasan Nuansa Cendekia. 